\title{
The Role of Media Advertising in the Development of Sports Tourism in Guilan Province of Iran
}

\author{
${ }^{1}$ Morteza Rezaei Soofi, ${ }^{2}$ Siavash Khodaparast ${ }^{*}$,Sina Eisazadeh \\ ${ }^{1}$ Department of Sport Management, Payam Noor University, Rasht, Iran. ${ }^{2}$ Department of Physical \\ Education and Sport Science, Lahijan Branch, Islamic Azad University, Lahijan, Iran.
}

Submitted 30 December 2019; Accepted in final form 20 September 2020.

\begin{abstract}
Background. The purpose of this study was to investigate the role of media advertising in the development of sports tourism in Guilan province. Methods. The research method is a descriptive-survey based on the structural equation model (Lisrel). The statistical population of the study was included managers of tourism, sport management professors, managers, and experts of tourism agencies that 362 persons were randomly selected. The instrument was included in a researcher-made questionnaire based on the Likert scale. The questionnaires were distributed among the subjects after the confirmation of the validity and reliability. Results. The results of the study showed that media advertising in sports tourism of Guilan province played the most critical role in the establishment of cultural tourism and the enhancement of the sports economy, the change of attitude in sport tourists' public opinion, the introduction of attractions for sports tourists' attraction, the development of tourism infrastructure and services, respectively. The results also showed that media advertising had the least effect on creating a comprehensive program of sports tourism marketing. Conclusion. Therefore, we have to pay attention to advertising and marketing to develop sports tourism due to their role in tourism packages.
\end{abstract}

\section{KEYWORDS: Media Advertising, Sports Tourism, Tourism Development, Cultural Tourism, Tourism Marketing.}

\section{INTRODUCTION}

The last century and the present century are media centuries. Man is now in the image era after the transition from speech and writing courses. An image in the media is stronger than speech and text because it has the most attractive and significant influence on the audience. There is no doubt that the media has a decisive effect on the creation of the mental image of the host and tourists' community (1). Mass media can best visualize a tourist area using advertising techniques, artistic creations, beauties, abilities, and potentials of an area. They can cause a pessimistic, negative mentality of an area. In other words, the media internalize, absorb, and nurture images that they have made themselves through persuasion and Intrusion into a human's mind (2). Tourism is a social phenomenon that every social phenomenon needs adequate hospitality, whether positive or negative, for its emergence in society. The media plays an essential role in the expansion or stagnation of related activities to this sector due to their capabilities. The media can shape individuals' thoughts in a society with precise and controlled planning. Those can manipulate individuals' behavior and can expand their viewpoints. Today, the media are the most powerful and most influential production tools of concepts, social proportions, and the messengers of culture in societies with modern and audience-friendly

*. Corresponding Author:

Siavash Khodaparast, Assistant Professor

E-mail: s.khodaparast@yahoo.com 
forms. Radio, television, publications, the internet, and modern media are indirect means of communication with the power of direction, applying taste, and mentalization and can be highly effective in tourism (3).

The media and its quantitative and qualitative advances in all dimensions of life and communications from various aspects are ahead of the recent movement. Illustration, need assessment, persuasion, awareness, effective communication, and modern technology are in the media field. It has placed many countries among the top destinations of tourist attractions in the world. Tourism, as a lucrative industry, has taken such a place in the current state of the world that it is not sensible to ignore the numerous benefits due to the development of communication technology and the formulation of labor and security laws. Researchers have classified sports tourism in different ways. Sports tourism is also one of the favorite branches of this industry. Redmond (1990) classifies sports tourism into various sports holidays, sports celebrations, world tournaments, museums, and famous sports venues. Planning for sports tourism is inherently complex and challenging. The most important reason and the biggest problem may be that sports tourism is a mix of the two distinct areas of tourism and sport. Each area is managed separately, which means no single entity takes overall responsibility for sports tourism (4). Organizations and experts in tourism and physical education should be in close contact to take advantage of sports tourism opportunities.

A review of previous studies showed different and varied results to explain the research problem. Nobakht et al. (2014) surveyed practical factors on developing sports tourism and executive solutions in Ardabil province. They found that related factors to entertainment and leisure activities, related factors to physical education, sports services, tourism factors, related factors to facilities and infrastructure, related factors to natural resources, related factors to information and communication services, welfare facilities, and related factors to transport were the factors that have contributed to the development of sport tourism in this province, respectively (5). Khaledian et al. (2013) examined the role of mass media in sports development. They concluded that mass media as information highways and significant communication bridges on public opinion played an essential role in information, discourse, education, social participation, sports culture in society, the promotion of sport, and its development in the country (6). Moeinfard et al. (2014) has surveyed strategies for the development of recreational sports tourism in Iran. They found that managers and planners of the tourism and sport sector of the country should make their effort to develop this industry due to the importance of sports tourism (7). It should also not be ignored the conscious and constructive interaction that there should be among the different effective departments, institutions, and organizations, and beneficiaries in the development of sports tourism. Karimi et al. (2015) examined the relationship between sports tourism and the development of urban selected dimensions in Tehran city (8). They concluded that held sport events in Tehran city could have long-term and indirect benefits and short-term and direct for the city. Lotfi and Heidari (2015) examined the role of media advertising and media marketing for sustainable tourism development in Iran (9). They stated that many factors could play a role in the development of tourism in Iran. The media have played a significant role in this field. Those have dominated all levels of political, economic, cultural, and social around the world with the help of its advanced technology. Thomas (2006) examined Canadian sport and culture in the tourism marketplace (10). He described sports successes in various arenas and sports stars and heroes' effects. Kennelly and Toohey (2014) examined the role of national sport organizations and NGOs in sports tourism they concluded that sports institutions and NGOs in cooperation with national unions and NGOs could play an important role to maximize the results of major sport tourism events (11). Kiralovc and Pavlíceka (2015) surveyed the development of social media strategies in a tourism destination. They stated that strategies that are coordinated with social media could help goals to maintain competitiveness in tourism destinations (12).

Fairley et al. (2016) studied image recovery from negative media coverage of a sporting event: destination, venue, and event considerations (13). They concluded that the successful holding of events depended on all aspects of the venue, the city, and the competition, and the events that took place there that if these events were adverse, would affect the negative media coverage of the international events of destination image of the host city. It will damage the image of the destination and will reduce tourist arrivals to these areas during the holding of sports events. Palrão 
and Filipe (2017) studied the importance of sporting events in tourism in Portugal (14). They concluded that sports events were significant in tourism. This relevance results mainly from the fact that numerous disciplines can be practiced, and nowadays, tourists are traveling around the world to participate in multiple sports events. According to this topic, it is necessary to study the different types of participation that tourists are involved with them in all sport processes to provide a context for the development of sport tourism according to people's preferences. Roig, et al., (2017) examined the effect of social media on tourism development found that the presence of media and social networks, especially Instagram, has caused tourism events that have included user initiative and empowerment, full organization and structure, great social media use and promotional videos production, brand dissemination, attraction capacity, strong online community bond, and faithfulness. Media and social networks have changed the management functions of the tourism structure in a modern way (3).

Guilan province is one of the northern provinces of Iran that its center is the Rasht metropolis. This province is bounded on the north by the Caspian Sea and Azerbaijan with an international border through Astara city. The province is bounded on the west by Ardebil province, south by Zanjan and Qazvin provinces, and on the east by Mazandaran province. Provinces such as Guilan Province located in a natural, pristine, coastal, mountainous, and forest area have specific aspects of sports tourism. They can be the favorite places for athletes and tourists. These places are chosen as a destination for leisure time with the motivation of recreation and leisure and can accommodate many tourists at a specific period. The presence of the Caspian Sea, prone coasts, great mountains, dense forests, lakes, dams, caves, and many different rivers are essential features of Guilan province that are very important for sports tourism. These characteristics of the province have made it possible to play various sports at any time of the year in its different places. Since there are numerous tourism capabilities and potentials in different cities and different parts of this province, it seems to be possible to provide citizen-oriented areas with a focus on sports tourism programs as well as the creation of urban attractions for tourists and integration of sports and tourism in the province through the formulation of proper planning and using proper media advertising.
Accordingly, we want to know how much media advertising has been influential in developing sports tourism in Guilan province.

\section{MATERIALS AND METHOD}

The study was descriptive-correlational and applied in terms of purpose.

Participants. The statistical population of the study was included experts of Cultural Heritage, Handicrafts and Tourism Organization, experts of travel services offices, tourism professors, sports coaches, physical education professors in higher education institutions of the province, and experts in the field of physical education $(\mathrm{N}=$ About 6,000 people). A sample size of 362 persons was calculated and selected using Cochran's sample size formula.

Instruments and Tasks. In this study, a researcher-made questionnaire was used, using theoretical foundations and semi-structured interviews. This questionnaire had two separate sections. The first part of the questionnaire included demographic characteristics of the statistical sample of the study. The second part of the questionnaire included five main variables of research. These main variables were the development of infrastructure and tourism services (questions 1-4), the creation of a comprehensive program of sports tourism marketing (questions 5-7), the attractions for sports tourists' attraction (questions 8-10), the change of attitudes in sports tourists' public opinion (questions 11-13), and the establishment of cultural tourism and enhancement of the sports economy (questions 14-20). Twelve experts confirmed the validity of the questionnaire. Its reliability was also calculated by Cronbach's alpha test (0.89).

Procedure. The purpose of the study was explained to the subjects. All subjects completed a consent form to participate in this study, and they attended with complete satisfaction in this study. The questionnaires were distributed among the subjects after the confirmation of the validity and reliability.

Data Analysis. The collected data were classified by descriptive statistical methods and were analyzed by t-test and SPSS software $(p<0.05)$. LISREL software was also used to model structural equations.

\section{RESULTS}

Research findings were analyzed with descriptive and inferential parts. The subjects' demographic characteristics have been shown in 
the descriptive section. The frequency, percentage of sex, age, educational degree, and work experience of subjects are listed separately (Table 1).

Table 1. The Statistical Description of the Sample

\begin{tabular}{|lcc}
\hline Variable & F & Frequency Percentage \\
\hline Gender & & 8.58 \\
$\quad$ Male & 213 & 2.41 \\
$\quad$ Female & 149 & 8.8 \\
$\quad$ Under 25 years old & 32 & 34.48 \\
\hline Age & & 1.40 \\
$\quad$ 26-30 years old & 175 & 2.4 \\
31-40 years old & 145 & 1.17 \\
$\quad$ Over 40 years old & 10 & 0.10 \\
$\quad$ Educational degree & 34 & 7.40 \\
Associate's degree & 101 & 5.7 \\
Bachelor's degree & 227 & 8.18 \\
$\quad$ Master's degree or higher & & 0.414 \\
Work experience & 27 & 6.53 \\
$\quad$ under 4 years & 68 & 9.22 \\
\hline 4-8 years & 52 & 100 \\
\hline 8-12 years & 194 & 32 \\
\hline 12-16 years & 362 & \\
\hline Over 16 years & & \\
\hline Total & & \\
\hline
\end{tabular}

Table 2. The Role of Media Advertising in the Development of Sport Tourism Infrastructure and Services in Guilan

\begin{tabular}{|c|c|c|c|c|c|c|c|}
\hline \multirow{3}{*}{ Criteria } & \multicolumn{3}{|c|}{ Province } & \multirow{3}{*}{ SD } & \multirow{3}{*}{$\begin{array}{c}\text { Mean } \\
\text { Difference }\end{array}$} & \multirow{2}{*}{\multicolumn{2}{|c|}{$\begin{array}{l}\text { 95\% Confidence } \\
\text { Interval of the } \\
\text { Difference }\end{array}$}} \\
\hline & $\mathbf{t}$ & Df & p & & & & \\
\hline & & & & & & Lower & Upper \\
\hline $\begin{array}{l}\text { Development of accommodation centers and } \\
\text { hotels }\end{array}$ & 11.238 & 361 & 0.001 & 0.90260 & 0.53315 & 0.4399 & 0.6264 \\
\hline $\begin{array}{l}\text { Improvement of reception centers and } \\
\text { restaurants }\end{array}$ & 29.062 & 361 & 0.001 & 0.66554 & 1.01657 & 0.9478 & 1.0854 \\
\hline $\begin{array}{l}\text { Development and improvement of the quality } \\
\text { of the transportation system and easy access } \\
\text { to tourism destinations }\end{array}$ & 16.008 & 361 & 0.001 & 0.75516 & 0.63536 & 0.5573 & 0.7134 \\
\hline $\begin{array}{l}\text { Establishment of standard recreational and } \\
\text { tourism centers and appropriate fitness clubs }\end{array}$ & 44.021 & 361 & 0.001 & 0.64116 & 1.48343 & 1.4172 & 1.5497 \\
\hline
\end{tabular}

Table 3. The results of one-sample t-test in the creation of a comprehensive program of sports tourism marketing in

\begin{tabular}{|c|c|c|c|c|c|c|c|}
\hline \multirow{3}{*}{ Criteria } & \multicolumn{4}{|c|}{ Guilan province } & \multirow{3}{*}{$\begin{array}{c}\text { Mean } \\
\text { Difference }\end{array}$} & \multirow{2}{*}{\multicolumn{2}{|c|}{$\begin{array}{l}95 \% \text { Confidence } \\
\text { Interval of the } \\
\text { Difference }\end{array}$}} \\
\hline & $\mathbf{t}$ & Df & $\mathbf{p}$ & SD & & & \\
\hline & & & & & & Lower & Upper \\
\hline $\begin{array}{l}\text { Recognition of target markets and sports } \\
\text { tourism segmentation }\end{array}$ & 14.682 & 361 & 0.001 & 0.84839 & 0.65470 & .5670 & .7424 \\
\hline $\begin{array}{l}\text { Introduction and promotion of the quality } \\
\text { of sports tourism packages for different } \\
\text { classes }\end{array}$ & 10.506 & 361 & 0.001 & 0.75543 & 0.41713 & .3390 & .4952 \\
\hline $\begin{array}{l}\text { The role of media advertising (especially } \\
\text { the internet and modern Media) in the } \\
\text { creation of a comprehensive program of } \\
\text { sports tourism marketing }\end{array}$ & 33.164 & 361 & 0.001 & 0.87482 & 1.52486 & 1.4344 & 1.6153 \\
\hline
\end{tabular}


Table 4 showed that media advertising played a significant role in introducing attractions for sports tourists' attraction to Guilan province. According to the findings, media advertising had the highest effect on information and sports tourism attractions advertising during the holding of events $(t=45.052)$. It had the least effect on events and attractions advertising after hosting tourist attractions $(\mathrm{t}=19.304)$.

The results in Table 2 showed that media advertising had the highest effect on establishing standard recreational and tourism centers and appropriate fitness clubs $(\mathrm{t}=44.021)$. It had the least effect on the development of accommodation centers and hotels $(t=11.238)$.

The results in Table 3 showed that media advertising played a role in creating a program comprehensive of sports tourism marketing in Guilan province. According to the findings and the experts' idea, the role of media advertising (especially the internet and modern media) in the creation of a comprehensive program of sports tourism marketing had the highest effect $(\mathrm{t}=$ 33.146). The introduction and promotion of the quality of sports tourism packages had the least effect $(\mathrm{t}=10.506)$.

Table 4. The Survey of the Role of Media Advertising in the Introduction of Attractions for Sports Tourists' Attraction in

\begin{tabular}{|c|c|c|c|c|c|c|c|}
\hline \multirow{3}{*}{ Criteria } & \multicolumn{3}{|c|}{ Guilan Province } & \multirow{3}{*}{ SD } & \multirow{3}{*}{$\begin{array}{c}\text { Mean } \\
\text { Differenc } \\
\text { e }\end{array}$} & \multirow{2}{*}{\multicolumn{2}{|c|}{$\begin{array}{l}95 \% \text { Confidence } \\
\text { Interval of the } \\
\text { Difference }\end{array}$}} \\
\hline & t & df & p & & & & \\
\hline & & & & & & Lower & Upper \\
\hline $\begin{array}{l}\text { Introduction of all kinds of natural and } \\
\text { ecotourism attractions of the host } \\
\text { community to sports tourists }\end{array}$ & 21.738 & 361 & 0.001 & 1.08320 & 1.23757 & 1.1256 & 1.3495 \\
\hline $\begin{array}{l}\text { Events and attractions advertising after } \\
\text { hosting for tourists' attraction }\end{array}$ & 19.304 & 361 & 0.001 & 0.88762 & 0.90055 & 0.8088 & 0.9923 \\
\hline $\begin{array}{l}\text { Information and sports tourism attractions } \\
\text { advertising during holding of events }\end{array}$ & 45.052 & 361 & 0.001 & 0.63698 & 1.50829 & 1.4424 & 1.5741 \\
\hline
\end{tabular}

Table 5. The Survey of the Role of Media Advertising in the Change of Sports Tourists' Attitudes and Public Opinions in

\begin{tabular}{|c|c|c|c|c|c|c|c|}
\hline \multirow[t]{2}{*}{ Criteria } & \multirow[t]{2}{*}{$\mathbf{t}$} & \multirow[t]{2}{*}{ Df } & \multirow[t]{2}{*}{$\mathbf{p}$} & \multirow[t]{2}{*}{ SD } & \multirow[t]{2}{*}{$\begin{array}{c}\text { Mean } \\
\text { Difference }\end{array}$} & \multicolumn{2}{|c|}{$\begin{array}{l}\text { 95\% Confidence } \\
\text { Interval of the } \\
\text { Difference } \\
\end{array}$} \\
\hline & & & & & & Lower & Upper \\
\hline $\begin{array}{l}\text { Public encouragement for participation in } \\
\text { sports and the optimization of leisure time } \\
\text { for tourists }\end{array}$ & 18.590 & 361 & 0.001 & 1.01783 & 0.99448 & 0.8893 & 1.0997 \\
\hline Importance of sports in public opinion & 27.114 & 361 & 0.001 & .86649 & 1.23481 & 1.1452 & 1.3244 \\
\hline $\begin{array}{l}\text { Creation of interest and motivation in } \\
\text { tourists with the aim of the combination of } \\
\text { sport and tourism }\end{array}$ & 34.334 & 361 & 0.001 & 60467 & 1.09116 & 1.0287 & 1.1537 \\
\hline
\end{tabular}

The results in Table 5 showed that media advertising played a significant role in the change of sports tourists' attitudes and public opinions in Guilan province. According to the findings, media advertising had the highest effect on the creation of interest and motivation in tourists with the aim of the combination of sport and tourism $(\mathrm{t}=34.334)$, and it had the least effect on public encouragement for sports participation and the optimization of leisure time for tourists $(t=18.590)$.

The results in Table 6 showed that media advertising played a significant role in the establishment of cultural tourism and reinforcement of the sports economy in Guilan province. According to the findings, media advertising had the highest effect on special attention of media to sports tourism advertising and the reinforcement of social and intercultural communication in sports competitions and festivals and the creation of an opportunity for players and coaches' exchange and the development of this industry $(t=57.957)$. It had the least effect on the reinforcement of the sociocultural aspects of sport in the representation and information about sports competitions $(t=16.122)$. 
Table 6. The Survey of the Role of Media Advertising in the Establishment of Cultural Tourism and Reinforcement of the Sports Economy in Guilan Province

\begin{tabular}{|c|c|c|c|c|c|c|c|}
\hline \multirow[t]{2}{*}{ Criteria } & \multirow[t]{2}{*}{$\mathbf{t}$} & \multirow[t]{2}{*}{ df } & \multirow[t]{2}{*}{ p } & \multirow[t]{2}{*}{ SD } & \multirow[t]{2}{*}{$\begin{array}{c}\text { Mean } \\
\text { Difference }\end{array}$} & \multicolumn{2}{|c|}{$\begin{array}{l}\text { 95\% Confidence } \\
\text { Interval of the } \\
\text { Difference }\end{array}$} \\
\hline & & & & & & Lower & Upper \\
\hline $\begin{array}{l}\text { Introduction of the culture, customs, and } \\
\text { developments of the host community }\end{array}$ & 21.456 & 361 & 0.001 & .96761 & 1.09116 & .9911 & 1.1912 \\
\hline $\begin{array}{l}\text { Reinforcement of the socio-cultural aspects of } \\
\text { the sport during the representation and } \\
\text { information about sports competitions }\end{array}$ & 16.122 & 361 & 0.001 & 1.00407 & 0.85083 & 0.7470 & 0.9546 \\
\hline $\begin{array}{l}\text { Special attention of media to sports tourism } \\
\text { advertising and the reinforcement of social } \\
\text { and intercultural communication in sports } \\
\text { competitions and festivals and the creation of } \\
\text { an opportunity for players and coaches' } \\
\text { exchange and the development of this industry }\end{array}$ & 57.957 & 361 & 0.001 & 0.56225 & 1.71271 & 1.6546 & 1.7708 \\
\hline $\begin{array}{l}\text { The attraction of public participation and } \\
\text { private sector investment for the } \\
\text { reinforcement of sports infrastructure and the } \\
\text { holding of cultural - sports festivals }\end{array}$ & 36.710 & 361 & 0.001 & 0.76311 & 1.47238 & 1.3935 & 1.5513 \\
\hline $\begin{array}{l}\text { Strengthening jobs such as tourism, hotel } \\
\text { management, and the improvement of staff } \\
\text { status of recreational places and sports clubs }\end{array}$ & 41.885 & 361 & 0.001 & 0.64498 & 1.41989 & 1.3532 & 1.4866 \\
\hline $\begin{array}{l}\text { Economical enhancement and increase of } \\
\text { income and entrepreneurship in the host } \\
\text { community }\end{array}$ & 34.105 & 361 & 0.001 & 0.73972 & 1.32597 & 1.2495 & 1.4024 \\
\hline $\begin{array}{l}\text { Encouragement of travel agencies for use of } \\
\text { recreational activities in travel packages }\end{array}$ & 30.379 & 361 & 0.001 & 0.76124 & 1.21547 & 1.1368 & 1.2942 \\
\hline
\end{tabular}

Table 7. The Survey of the Role of Media Advertising in the Development of Sports Tourism in Guilan Province

\begin{tabular}{|c|c|c|c|c|c|c|c|c|}
\hline \multicolumn{9}{|c|}{ One-Sample Test } \\
\hline \multirow[t]{3}{*}{ Criteria } & \multicolumn{8}{|c|}{ Test Value $=\mathbf{3}$} \\
\hline & \multirow[t]{2}{*}{ Mean } & \multirow[t]{2}{*}{$\mathbf{t}$} & \multirow[t]{2}{*}{ df } & \multirow[t]{2}{*}{$\mathbf{p}$} & \multirow[t]{2}{*}{ SD } & \multirow[t]{2}{*}{$\begin{array}{c}\text { Mean } \\
\text { Difference }\end{array}$} & \multicolumn{2}{|c|}{$\begin{array}{l}\text { 95\% Confidence } \\
\text { Interval of the } \\
\text { Difference }\end{array}$} \\
\hline & & & & & & & Lower & Upper \\
\hline $\begin{array}{l}\text { Development of tourism } \\
\text { infrastructure and services }\end{array}$ & 3.9171 & 26.575 & 361 & 0.001 & 0.65661 & 0.91713 & 0.8493 & 0.9850 \\
\hline $\begin{array}{l}\text { Creation of a comprehensive } \\
\text { program of sports tourism } \\
\text { marketing }\end{array}$ & 3.8656 & 23.943 & 361 & 0.001 & 0.68783 & 0.86556 & 0.7945 & 0.9367 \\
\hline $\begin{array}{l}\text { Introduction of attractions for } \\
\text { sports tourists' attraction }\end{array}$ & 4.2155 & 29.784 & 361 & 0.001 & 0.77645 & 1.21547 & 1.1352 & 1.2957 \\
\hline $\begin{array}{l}\text { Change of attitudes in sports } \\
\text { tourists' public opinion }\end{array}$ & 4.1068 & 30.402 & 361 & 0.001 & 0.69267 & 1.10681 & 1.0352 & 1.1784 \\
\hline $\begin{array}{l}\text { Establishment of cultural tourism } \\
\text { and the enhancement of sports } \\
\text { economy }\end{array}$ & 4.2983 & 35.973 & 361 & 0.001 & 0.68669 & 1.29834 & 1.2274 & 1.3693 \\
\hline
\end{tabular}

The results in Table 7 showed that media advertising played a useful role in developing sports tourism in Guilan province $(\mathrm{p}<0.05)$. According to the findings, media advertising had the highest effect on the establishment of cultural tourism and the enhancement of the sports economy $(t=35.973)$, and it had the least effect on the creation of a comprehensive program of sports tourism marketing $(\mathrm{t}=23.943)$.

\section{DISCUSSION AND CONCLUSION}

The purpose of this study was to investigate the role of media advertising in the development of sports tourism in Guilan province. According to the conducted studies, the variables have been examined in this regard that we will discuss their results. The development of accommodation centers and hotels, the improvement of reception centers and restaurants, the improvement of the 
quality of transport system and easy access to tourist destinations (such as road improvement, road signs, etc.), and the creation of standard recreational and tourist centers and fitness clubs' indicators were evaluated to examine the relationship between the effect of media advertising on the development of infrastructure and tourism services. The obtained results showed that media advertising played a role in the development of tourism infrastructure and services that media advertising had the highest effect on the creation of standard recreational and tourism centers and fitness clubs, the improvement of the status of reception centers and restaurants, the improvement of the quality of transport system and easy access to tourist destinations (such as road improvement, road signs, etc.), and the development of accommodation centers and hotels, respectively. These results are consistent with the results of Nobakht et al. (2014) and Roig et al. 's (2017) study. Nobakht et al. (2014) concluded in their study that related factors to entertainment and leisure activities, related factors to physical education, sports services, tourism factors, related factors to facilities and infrastructure, related factors to natural resources, related factors to information, and communication services, welfare facilities, and related factors to transport were the factors that have contributed to the development of sport tourism in this province, respectively $(3,5)$.

It was observed that media advertising could be useful in the creation of a comprehensive program of sport tourism marketing in Guilan province. The variables that were studied in this hypothesis included the recognition of the target markets and segmentation of sports tourism, the introduction and promotion of the quality of sports tourism packages for different classes, and media advertising (especially internet and modern media) in the creation of a comprehensive program of sports tourism marketing. The results of the t-test showed that media advertising had the highest effect on the role of media advertising (especially internet and modern media) in the creation of a comprehensive program sports tourism marketing, media advertising in the field of sports tourism in recognition of target markets and the segmentation of this type of tourism and media advertising in the introduction and promotion of the quality of sports tourism packages for different classes, respectively. Javid et al. (2012) found in their study that two factors were identified as tour packages and attraction advertising. The factor analysis also identified the index of proper and faster use of information and advertising sources in the component of tourism packages and the index of the introduction of attractions for sports tourists in attractions advertising as important indexes in sports tourism development (15).

It was stated that media advertising could play an influential role in introducing attractions for sports tourist's attraction in Guilan province. The variables that were studied in this hypothesis included the introduction of all kinds of natural and ecotourism attractions of the host community to sports tourists, events and attractions advertising after hosting for tourists' attraction, and information and sports tourism attractions advertising during the holding of events. The results showed that media advertising had the highest effect on information, the introduction of all kinds of natural and ecotourism attractions of the host community to sports tourists sports tourism attractions advertising during the holding of events, and attractions advertising after hosting for tourists' attraction. The results of this hypothesis are consistent with the results of Javid et al. (2012) and Fairley et al. 's (2016) studies $(13,15)$. They found that the successful holding of events depended on all aspects of the venue, the city, and the competition, and the events that took place there that if these events were adverse, would affect the negative media coverage of the international events of destination image of the host city. It will damage the image of the destination and will reduce tourist arrivals to these areas during the holding of sports events. On the other hand, Hamidi (2014) also concluded in her study that successful media productions could significantly affect the introduction of lowinterest attractions in areas with tourism potential. Tourism places could directly affect media activity on the development of related activities to this sector, and sports tourism was one of the growing sectors of the tourism industry in the world (16).

It was also observed that media advertising could play a role in changing sports tourists' attitudes and public opinions in Guilan province. The variables that were studied in this hypothesis included public encouragement for sports participation and the optimization of leisure time for tourists, the importance of sports in public opinion, and the creation of interest and motivation in tourists with the aim of the 
combination of sport and tourism the results showed media advertising had the highest effect on the creation of interest and motivation in tourists with the aim of the combination of sport and tourism and the encouragement for sports participation and the optimization of leisure time for tourists. These results are consistent with the results of Khaledian et al. (2013) and Palrão and Filipe's (2017) studies (6, 14). They concluded that mass media as information highways and significant communication bridges on public opinion played an essential role in information, discourse, education, social participation, sports culture in society, the promotion of sport, and its development in the country.

They were finally observed that media advertising could play a role in the establishment of cultural tourism and reinforcement of the sports economy in Guilan province. The variables that were studied in this hypothesis included the introduction of the culture, customs, and developments of the host community, the reinforcement of the socio-cultural aspects of the sport during the representation and information about sports competitions, the reinforcement of social and intercultural communication in sports competitions and festivals and the creation of an opportunity for players and coaches' exchange and the development of this industry, the attraction of public participation and private sector investment for the reinforcement of sports infrastructure and the holding of cultural - sports festivals, strengthening jobs such as tourism, hotel management, and the improvement of staff status of recreational places and sports clubs, the economic enhancement and increase of income and entrepreneurship in the host community, and the encouragement of travel agencies for the use of recreational activities in travel packages. The results showed that media advertising had the highest effect on special attention of media to sports tourism advertising, the reinforcement of social and intercultural communication in sports competitions and festivals, and the creation of an opportunity for players and coaches' exchange and the development of this industry, strengthening jobs such as tourism, hotel management, and the improvement of staff status of recreational places and sports clubs, the attraction of public participation and private sector investment for the reinforcement of sports infrastructure and the holding of cultural - sports festivals, the economic enhancement, and increase of income and entrepreneurship in the host community, the encouragement of travel agencies for the use of recreational activities travel packages, and the reinforcement of the socio-cultural aspects of the sport during the representation and information about sports competitions, respectively. These results are consistent with the results of Thomas (2006) and Királ'ová and Pavlíčeka's (2015) study (10, 12). Thomas (2006) examined Canadian sport and culture in the tourism marketplace and categorized the effects of sport on the economy and tourism culture. He described sports-cultural and economic successes in various arenas and sports stars and heroes' effects. Today, tourism in many areas is an important economic activity in the service sector (10).

The conducted studies show that sports tourism is one of the fastest-growing sectors in the tourism industry worldwide and has high economic potential. Sports tourism events play an essential role in this market, and the number of destinations that sports events incorporate into their marketing mix is always growing. According to the relevance of choosing a place for tourism with its sports activities, competitions, and sporting events contribute to the development of tourism in the country that will attract many tourists. The results of the present study showed that different components must be considered for the development of sport tourism. These components can include advertising, marketing, the recognition of capabilities and the introduction of attractions, the change of attitudes in public opinion, exceptional attention to culture and the enhancement of the sports economy, and the development of infrastructure, facilities, and places. The advertising and marketing component is identified as the most crucial component of advertising for the design of sports tourism packages. Therefore, advertising and marketing are significant that should consider their position due to their role in tourism packages. It was expressed that the purpose of advertising is a significant increase in marketing and market growth, and any neglect and misuse of this tool not only will result in failure but also will result in the backwardness of competitions and correct and principled marketing in the international arena. Marketing and promotion are essential for the successful development of sports tourism; however, they are often seen with a simple look. Traditional sports tourism marketing focuses more on tourist's goals than on new and different ways. Also, the marketing of tourism industry products is 
increasingly complex. The interconnected concept conveys an image of one place and an attempt to convey the experience of a stage of life from one customer to another. According to the findings of this study, media advertising in sports tourism of Guilan province played the most critical role in the establishment of cultural tourism and the enhancement of the sports economy, the change of attitude in sport tourists' public opinion, the introduction of attractions for sports tourists' attraction, the development of tourism infrastructure and services, respectively. Media advertising had the least effect on the creation of a comprehensive program of sports tourism marketing. Therefore, tourism and physical education experts and managers in Guilan province should pay more attention to the weaknesses and challenges of this industry and emphasize the role of the media in the creation of a comprehensive program of sports tourism marketing. The mass media play a significant role in the development of the tourism industry and the identification and introduction of tourism attractions. They can provide a suitable background for the implementation and completion of tourism plans in this way.

The most important task of the media is to visualize and create mental real and unreal images. The media plays a vital role in presenting real and unreal images of the regions due to its extensive capabilities in audiences' attraction and the ability to shape public opinion. Besides, the imagery of different places and countries and shaping geographical imaginations are significant for individuals. People's perceptions of a particular region or country can be shaped by forms of popular culture in the media such as movies, television, and the polite components of that country. Tourists are stimulated and impressed through the derived concepts from the media and the interactions communication that they face in their daily lives.

It should be noted that interaction between the media and tourism provides opportunities for a deeper understanding of tourists' consumption patterns that shapes the way and mechanism of the production of all kinds of goods and services inevitably. Therefore, tourism media is a field of study that may significantly increase our awareness of tourism processes and functions. Tourism is one of the most critical needs and activities for the modern man. On the other hand, the discussion of the relationship between tourism and the media has a close relationship with the social, economic, and cultural development of societies. Media, as a cultural tool, also plays an essential role in imagery and tourism.

\section{APPLICABLE REMARKS}

- Finally, it is recommended to design comprehensive websites for the marketing of attractions that have the potential of sports tourism in Guilan province.

- It is also recommended that specialty television channels be established for tourism and sports tourism due to the marketing and advertising of sports tourism events and potentials in Guilan province.

- On the other hand, it is possible to develop cultural tourism programs on the radio to develop sports tourism in the province due to its cheapness and easy access to the radio.

- There are also measures such as need assessment, persuasion, awareness, effective communication, and modern technologies in the media field that attract tourists in different fields.

- Therefore, it is suggested to encourage people to watch and participate in these events through the imagery of the various sports facilities, capabilities, and attractions in Guilan province.

\section{REFERENCES}

1. Karroubi M. Mass media and tourism destination selection. Tourism Manage Stud. 2011;6(15):11-136.

2. Mohammadi N, Rezaei A. Modern media and semantic understanding of leisure experience (a case study: students of Mazandaran University). Cultur Stud Communicat. 2014;15(27):163-184.

3. Roig EM, Martin-Fuentes E, Daries-Ramon N. User-Generated Social Media Events in Tourism. Sustainabilit. 2017;9:1-22. doi: 10.3390/su9122250

4. Deery M, Jago L. The management of sport tourism. . Sport Societ. 2005;8(2):263-279. doi: 10.1080/17430430500087328

5. Nobakht F, Atghia N, Amiri M, Gharakhani H, Ashrafi N. The survey of effective factors on the development of sports tourism in Ardabil province and presentation of executive solutions (2014). Sport Sci Quarter. 2014;6(13):103-123. 
6. Khaledian M, Mostafaei F, Samadi M, Kia F. The role of mass media in sport development. Communicat Manage Sport Media. 2013;1(2):48-56.

7. Moeinfard MR. Strategies for development of recreational sport tourism in Iran. Sport Manage Develop. 2014;3(2):1-17.

8. Karimi T, Honarvar A, Ashraf Ganjavi F. The relationship between sports tourism and development of urban selected dimensions in Tehran city. Sport Manage Develop. 2015;4(2):96-110.

9. Lotfi H, Heidari E. The survey of the role of media advertising and media marketing for sustainable tourism development in Iran. The First Scientific Research Conference on Modern Horizons in Geography and Planning, Architecture and Urban Planning of Iran. Scientific association of the Development and Promotion of Fundamental Science and Technology, Tehran 2015. Available from: www.civilica.com/Paper-NICONF01-NICONF01_329.htm.

10. Thomas H. Canadian Sport and Culture in the Tourism Marketplace. Tourism Geograph. 2006;8(1):1530. doi: 10.1080/14616680500392440

11.M. K, Toohey K. Strategic alliances in sport tourism: National sport organizations and sport tour operators. Sport Manage Rev. 2014;17(4):407-418. doi: 10.1016/j.smr.2014.01.001

12.Királ'ová A, Pavlíčeka A. Development of Social Media Strategies in Tourism Destination. Procedia Soc Behav Sci. 2015;175:358-366. doi: 10.1016/j.sbspro.2015.01.1211

13. Fairley Sh, Lovegrove H, Newland BL, Green BC. Image recovery from negative media coverage of a sport event: Destination, venue, and event considerations. Sport Manage Rev. 2016;19(3):352-360. doi: 10.1016/j.smr.2015.08.005

14.Palrão T, A. FJ. Sport Events Tourism: An Approach to the Portuguese Case. Int J Latest Trend Finance Economic Sci. 2017;7(2):1320-1334.

15.Javid M, Asadi H, Goudarzi M, Mohammadi E. The role of internet and modern media in sport tourism marketing. Appl Res Sport Manage. 2012;3:43-49.

16. Hamidi E. The survey of the role of media in sports tourism development. 1st Congress of Municipal Management and City councils. Sari city, Iran. 2014. 